\title{
MITRAL VALVE DISEASE WITH VENTRICULAR SEPTAL DEFECT
}

\author{
BY \\ ARTHUR HOLLMAN* AND M. HAMED $\dagger$ \\ From the Department of Medicine (Clinical Cardiology), Postgraduate Medical School and Hammersmith Hospital, \\ and from University College Hospital, London \\ Recejved July 20, 1964
}

Although congenital mitral valve disease is well known as an essential feature of persistent common atrio-ventricular canal (Campbell and Missen, 1957), and in association with corrected transposition of the great arteries (Helmholz, Daugherty, and Edwards, 1956), it is much less common apart from these anomalies. Up to 1954 Ferencz, Johnson, and Wiglesworth could find only 34 reported cases, to which they added 9 of their own, and in a review of 357 cases studied pathologically at the Mayo Clinic by Fontana and Edwards (1962) there were only 3 with congenital mitral value disease. However, the practical importance of the subject was demonstrated by the pioneer surgical work of Bower et al. in 1953, and we now wish to report our own experience of the lesion in association with ventricular septal defect.

\section{The Patients}

From 1958 to 1963221 patients with ventricular septal defect (VSD) were studied in the Department of Medicine at Hammersmith Hospital, and 97 of these were found to have associate anatomical cardiac defects (Table I). Excluding those with corrected transposition of the great arteries, there were 8 patients with mitral valve disease, and they form the basis of this report. Of the 8 patients, 6 were among the total of 169 who had surgical closure of the ventricular septal defect performed, and in one of them simultaneous mitral surgery was undertaken. Operations were performed by Mr. W. P. Cleland and Mr. H. H. Bentall using cardio-pulmonary bypass under the direction of Dr. Denis Melrose.

There were 4 males and 4 females and their ages ranged from 4 years to 22 years (average 10 years). A Morgagni type hiatus hernia, a squint, and epilepsy occurred in 3 patients, and one had paraplegia from previous poliomyelitis, but otherwise there were no extracardiac anomalies.

\section{Clinical Features}

Symptoms. During infancy 5 of the patients were ill with feeding difficulties, failure to gain weight, dyspnœa, and respiratory infections, but the other 3 were well. In childhood all but one had dyspnœa on exertion and fatigue; repeated attacks of bronchitis or pneumonia occurred in 6 . Patient No. 4 had congestive heart failure at the age of 3. Hæmoptysis was associated with the respiratory infections in 3, but it was slight and did not occur at other times. Angina pectoris was present during exertion in 5 patients, and cyanosis on exertion in one (No. 1). In another (No. 8) there were no symptoms until dyspnœa and palpitations developed during her third pregnancy at the

* Supported by a grant from the Rockefeller Fund, University College Hospital Medical School.

$\uparrow$ On study leave from the Egyptian Army Medical Corps. 
TABLE I

Associated Anatomical Abnormalities in 221 Patients with Ventricular Septal Defect

\begin{tabular}{|c|c|c|c|c|}
\hline & & & $\begin{array}{c}\text { Surgical } \\
169 \text { patients }\end{array}$ & $\begin{array}{c}\text { Medical } \\
52 \text { patients* }\end{array}$ \\
\hline $\begin{array}{l}\text { Pulmonary stenosis (infundibular } \\
\text { Aortic valve disease } \\
\text { Patent ductus } \\
\text { Multiple ventricular defects } \\
\text { Mitral valve disease } \\
\text { Atrial septal defect ... } \\
\text { Double outlet right ventricle } \dagger \\
\text { Single ventricle } \\
\text { Corrected transposition } . . \\
\text { Pulmonary artery abnormalities }\end{array}$ & 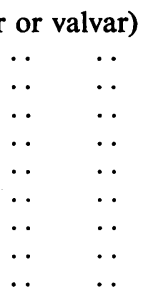 & $\begin{array}{l}. \\
\ldots \\
\therefore \\
\therefore \\
\therefore \\
\therefore \\
\therefore \\
\therefore\end{array}$ & $\begin{array}{r}19 \\
12 \\
11 \\
10 \\
6 \\
4 \\
3 \\
3 \\
3 \\
2\end{array}$ & $\begin{array}{r}1 \\
2 \\
1 \\
0 \\
2 \\
0 \\
2 \\
2 \\
12 \\
2\end{array}$ \\
\hline Pulmonary artery abnormalities & & & 73 & 24 \\
\hline
\end{tabular}

* Including 22 patients with the Eisenmenger syndrome.

$\dagger$ Morgan et al. (1962)

age of 20. No patient had a history of rheumatic fever or chorea. The mother of one (No. 4) had rubella at the third month of the pregnancy.

Physical Findings. There was physical maldevelopment in 7 patients: subnormal height or weight in 6 and a tall thin habitus associated with a high arched palate in the seventh. Four of them had a bulging chest (Cleland et al., 1958), and none had cyanosis or clubbing at rest though exertional cyanosis occurred in one (No. 1) who had a resting arterial saturation of 85 per cent. The facial appearances were normal and none were mentally retarded.

The jugular venous pulse was abnormal in 5 showing a prominent $a$ wave in 4 and large $a$ and $v$ waves in the fifth. No patient had congestive failure. The pulse volume was small in all except one and the quality was normal, as was the blood pressure. The rhythm was irregular from atrial fibrillation in patient No. 5. The cardiac impulses gave evidence of biventricular hypertrophy in all except patient No. 1 in whom the left ventricle was not palpable: this patient had tight mitral stenosis and severe pulmonary vascular disease.

Auscultation at the mitral area disclosed an accentuated first sound in 2 patients and an opening snap in 1 (Fig. 1). A pansystolic mitral murmur was heard in 3 patients (Fig. 2) and was followed by a moderate or long mitral diastolic murmur. The systolic murmur was conducted to the axilla and was accompanied in one by a thrill. In 5 patients there was a long mitral diastolic murmur with no systolic murmur, and it was accompanied by a thrill in 2 and was followed by a presystolic murmur in 3 (Fig. 3). In Patient No. 2 the presystolic murmur was much louder in inspiration.

At the left sternal edge the systolic murmur of the VSD was heard in all patients, being modified by the accompanying pulmonary hypertension (Hollman et al., 1963), so that a thrill was absent in 4, and the configuration of the murmur was pansystolic in 1, long ejection in 6 (Fig. 1), and short ejection in 1 (Fig. 3). At the pulmonary area the second sound was loud and narrowly split in all. There was an ejection click in 3 patients and a pulmonary diastolic bruit in 2 . Aortic and tricuspid murmurs were absent in all patients.

\section{THE EleCTROCARDIOGRAM}

The cardiographic findings varied according to the type and severity of the mitral lesion, and with the level of the pulmonary hypertension (Hollman, Goodwin, and Basta, 1962). In 5 patients with pure mitral stenosis the cardiogram showed lone right ventricular hypertrophy in 1 (Fig. 4), bi-ventricular hypertrophy with emphasis on the right ventricle in 3 , and slight bi-ventricular 


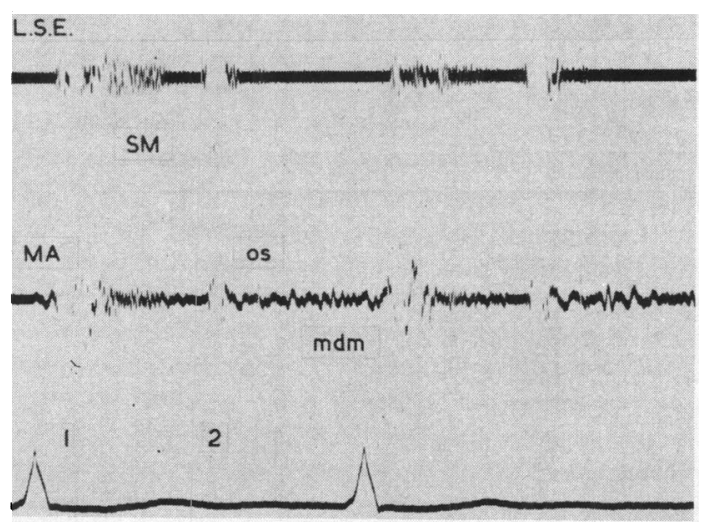

FIG. 1.-Phonocardiogram in patient 5 with mitral stenosis showing a loud first sound and an opening snap in addition to a long mitral diastolic murmur. The ventricular septal defect murmur tails off in late systole from moderate vascular disease. Atrial fibrillation is present. (L.S.E.=left sternal edge; $M A=$ mitral area; os=opening snap; $\mathrm{mdm}=$ mid-diastolic murmur).
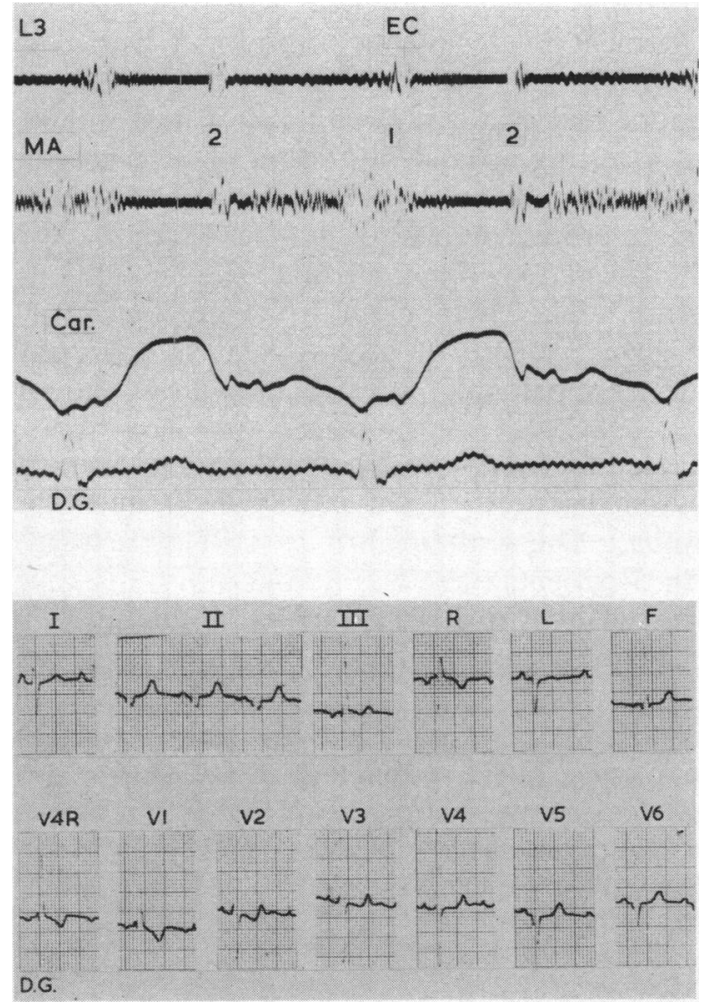

FIG. 4.-Electrocardiogram in patient 1 with severe mitral stenosis and severe pulmonary vascular disease with only a small left-to-right shunt showing right ventricular hypertrophy but $\mathrm{q}$ waves in V5 and 6. There is no left atrial P wave.

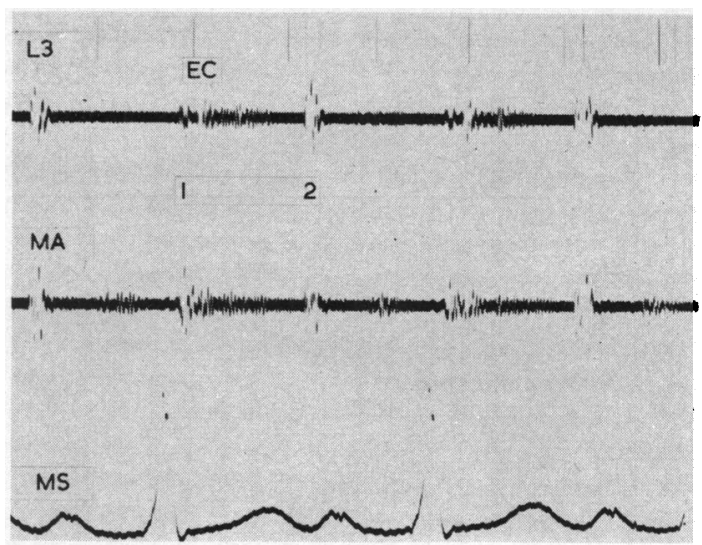

FIG. 2.-Phonocardiogram in patient 6 (MS) with mitral incompetence showing how the pansystolic mitral murmur contrasts with the ventricular septal defect murmur which has been shortened by pulmonary vascular disease. (MA =mitral area; L3 EC = lead 3 of electrocardiogram; $1=1$ st sound; $2=2$ nd sound.)

FIG. 3.-Phonocardiogram in patient 1 (D.G.) showing a loud presystolic murmur indicating the presence of organic mitral stenosis. Note the very short and soft ventricular septal defect murmur. (Car.= carotid sphygmogram.)

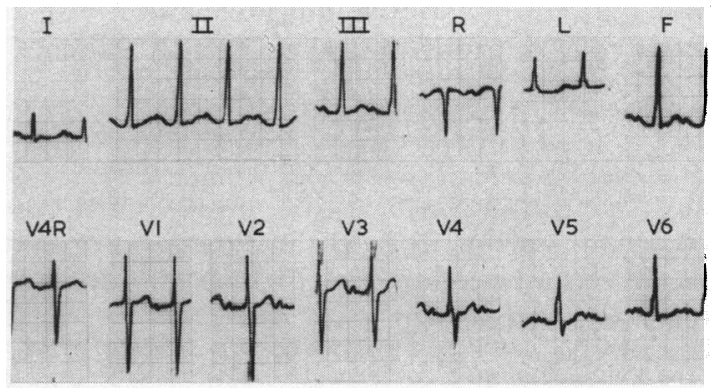

FIG. 5.-Electrocardiogram in patient 6 with mitral incompetence, a large left-to-right shunt and only moderate pulmonary vascular disease, showing a prominent left atrial $P$ wave and biventricular hypertrophy. 


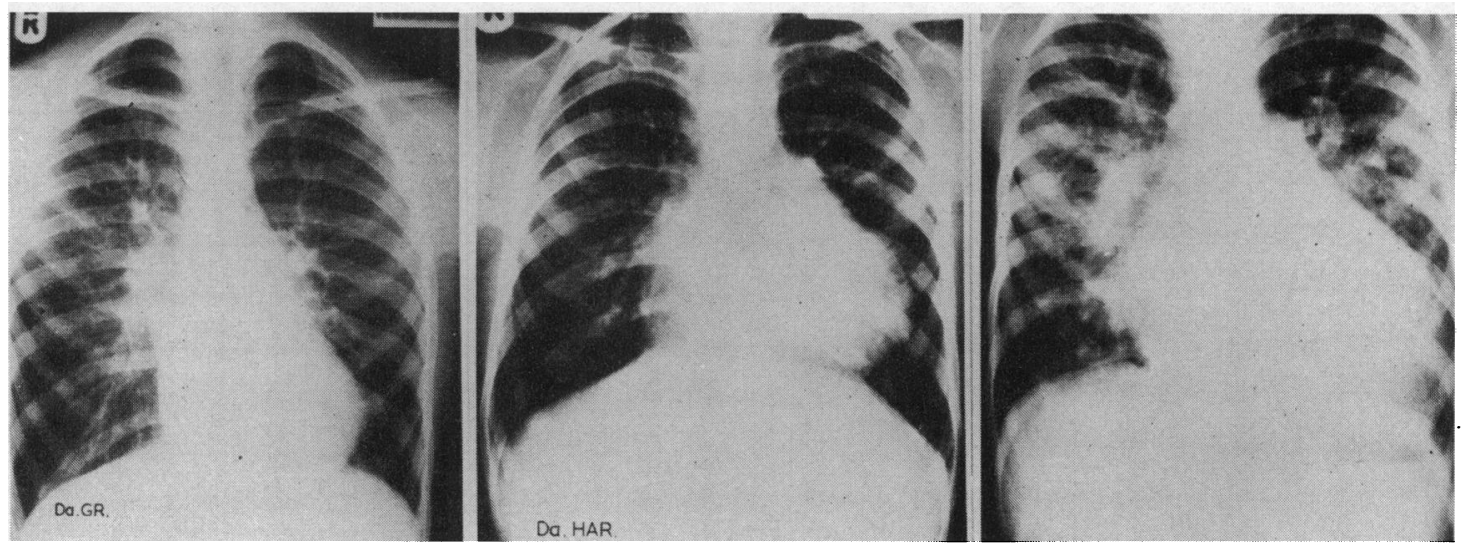

FIG. 6.-Radiographs from patients 1,3 , and 4 showing the considerable variation in heart size and in the lung vessels according to the type and severity of the mitral lesion and the extent of associated pulmonary vascular disease.

hypertrophy in the fifth. In the 3 patients with mitral incompetence there was lone left ventricular hypertrophy in 1, and bi-ventricular hypertrophy with the emphasis on the left ventricle in 2 . Deep $\mathrm{Q}$ waves in V5 to V7 were present in 1 patient who had only mild pulmonary vascular disease.

Right bundle-branch block with a QRS duration of 0.09 to $0.11 \mathrm{sec}$. was found in 3 . The electrical axis was deviated to the right in all except the one with severe mitral incompetence who had left axis deviation. Left atrial hypertrophy was found in 5, but was marked in only 1 (Fig. 5); right atrial hypertrophy was also found in 5 and was severe in 2.

\section{RADIOLOGY}

A plain radiograph of the chest was taken in all patients, a selective right atrial or right ventricular angiocardiogram in 6, and a selective left ventricular angiocardiogram in 3 patients. The overall heart size varied from 50 per cent in patient No. 1 to 70 per cent in patient No. 4, and averaged 65 per cent (Fig. 6).

Cardiac Chambers. The left atrium varied in size considerably (Table II). It was only slightly dilated in patient No. 1 with the tightest mitral valve, but was huge in patient No. 7 with severe mitral incompetence. The size seemed to be mainly determined by the type and severity of the mitral lesions on the one hand and the severity of pulmonary vascular disease and pulmonary blood flow on the other, and in the patients with pure mitral stenosis the size was never impressive. The left ventricle similarly was very big in those with mitral incompetence, but dilated only moderately in the stenotic patients. The right atrium was unduly conspicuous only in the patient (No. 4) with an associated atrial septal defect. The right ventricle was moderately dilated in all patients.

Great Arteries. The main pulmonary artery was dilated in every case, being slight in degree in one (No. 1), huge in the 2 adults even though one had only slight mitral stenosis, and moderate in size in the remainder. The aorta was hypoplastic in all and in one (No. 7) there was a right aortic arch.

Pulmonary Vessels. In view of the findings in rheumatic mitral stenosis (Goodwin, Steiner, and Lowe, 1952), the pulmonary arteries and veins were studied with particular interest. The typical disparity between the upper and lower zones with pulmonary venous dilatation in the former and pulmonary artery narrowing in the latter was excellently seen in patient No. 1 (Fig. 7) where there was severe mitral stenosis with only a tiny left-to-right shunt. In the other patients, pulmonary plethora was the main feature, but in one (No. 2), with moderately severe stenosis, the venous and arterial changes were clearly visible.

Faint interlobular B lines of Kerley were seen in 3 patients (No. 1, 2, and 5). 
TABLE II

Summary of the Main Clinical Features

\begin{tabular}{|c|c|c|c|c|c|c|}
\hline $\begin{array}{l}\text { Patient } \\
\text { No. }\end{array}$ & $\begin{array}{l}\text { Age } \\
\text { (yr.) }\end{array}$ & $\begin{array}{l}\text { Valve } \\
\text { lesion }\end{array}$ & $\begin{array}{l}\text { Pulmonary } \\
\text { vascular } \\
\text { disease }\end{array}$ & - Mitral bruits & Electrocardiogram & Radiograph \\
\hline 1 & 12 & MS severe & Severe & $\begin{array}{l}\text { Presystolic and } \\
\text { diastolic thrills }\end{array}$ & $\begin{array}{l}\text { RA } 1+, \text { LA } 0 \\
\text { RV } 3+, \text { LV } 0\end{array}$ & $\begin{array}{l}\mathrm{Ctr} 50 \% \text { LA } 1+; \\
\text { dilated upper lobe } \\
\text { veins. B lines }\end{array}$ \\
\hline 2 & 9 & MS moderate & Moderate & $\begin{array}{l}\text { Presystolic and dia- } \\
\text { stolic thrills }\end{array}$ & $\begin{array}{l}\text { RA } 1+, \text { LA } 2+ \\
\text { RV } 3+, \text { LV } 1+\end{array}$ & $\begin{array}{l}\text { Ctr } 59 \% \text { LA } 2+; \\
\text { dilated upper lobe } \\
\text { veins. B lines }\end{array}$ \\
\hline 3 & 5 & MS mild & Mild & Loud, $\frac{3}{4}$ length dia- & RA $1+$, LA $1+$ & $\mathrm{Ctr} 62 \%$ LA $2+$ \\
\hline 4 & $4 \frac{1}{2}$ & $\underset{\text { mild }}{\mathrm{MI}+\mathrm{MS}}$ & Mild & $\begin{array}{l}\text { Loud systolic, loud } \\
\frac{3}{4} \text { length diastolic } \\
\text { murmurs }\end{array}$ & $\begin{array}{l}\text { RA } 3+, \text { LA } 1+ \\
\text { RV } 2+, \text { LV } 2+\end{array}$ & $\begin{array}{l}\mathrm{Ctr} 70 \%, \text { LA } 3+; \\
\quad \text { dilated upper lobe } \\
\text { veins (slight) }\end{array}$ \\
\hline 5 & 19 & MS mild & Moderate & $\begin{array}{l}\text { Soft } \frac{3}{4} \text { length dia- } \\
\text { stolic murmur; } \\
\text { loud opening snap }\end{array}$ & $\begin{array}{c}\text { Atrial fibrillation } \\
\text { RV 1+, LV 1+ }\end{array}$ & $\begin{array}{l}\mathrm{Ctr} 72 \% \mathrm{LA} 2+; \\
\quad \mathrm{B} \text { lines }\end{array}$ \\
\hline 6 & 4 & & Moderate & $\begin{array}{l}\text { Systolic and diastolic } \\
\text { thrills }\end{array}$ & $\begin{array}{l}\text { RA } 0, \text { LA } 3+ \\
\text { RV } 1+, \text { LV } 2+\end{array}$ & $\mathrm{Ctr} 62 \%$ LA $2+$ \\
\hline 7 & 6 & MI severe & Severe & $\begin{array}{l}\text { Loud systolic; } \\
\text { moderately loud } \\
\text { and long diastolic } \\
\text { murmurs }\end{array}$ & $\begin{array}{l}\text { RA 0, LA 2+ } \\
\text { RV 0, LV } 4+\end{array}$ & $\begin{array}{l}\mathrm{Ctr} 64 \% \text { LA } 3+: \\
\quad \text { right arch }\end{array}$ \\
\hline 8 & 22 & MS moderate & Severe & $\begin{array}{l}\text { Loud presystolic and } \\
\text { diastolic murmurs }\end{array}$ & $\begin{array}{l}\text { RA } 3+, \text { LA } 2+ \\
\text { RV } 3+, \text { LV } 1+\end{array}$ & $\mathrm{Ctr} 65 \%$ LA $2+$ \\
\hline
\end{tabular}

$\mathrm{MS}=$ mitral stenosis; $\mathrm{MI}=$ mitral incompetence; $\mathrm{RA}=$ right atrium; $\mathrm{RV}=$ right ventricle $\mathrm{LA}=$ left atrium; $\mathrm{LV}=$ left ventricle; $\mathrm{Ctr}=$ cardiothoracic ratio; $\mathrm{B}$ lines=horizontal costophrenic lines.

Mitral Valve. The presence of incompetence was demonstrated directly from a left ventricular angiocardiogram in 2 patients and was seen to be mild in one (No. 6) and severe in one (No. 7) (Fig. 8). A competent mitral valve was shown in No. 8. A narrowed mitral orifice was never
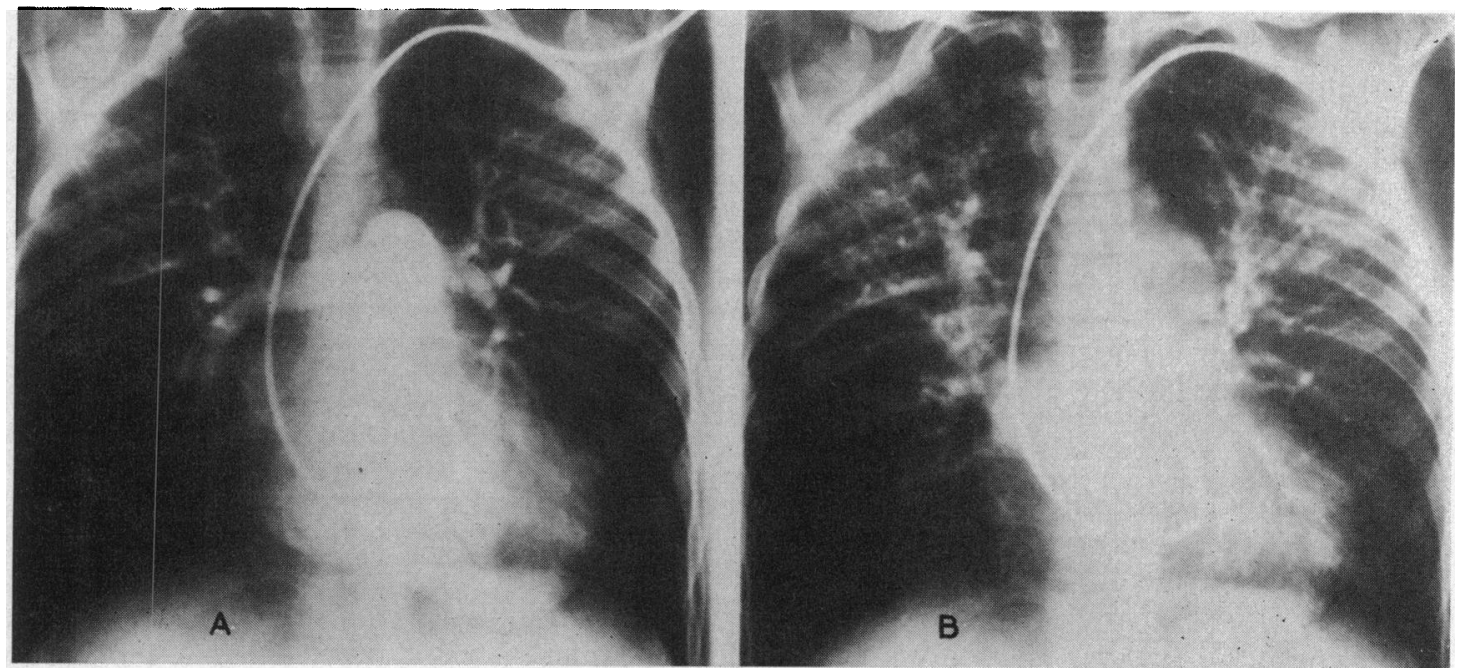

FIG. 7.-Angiocardiogram in patient 1 showing the arterial narrowing in the lower lobes (A) and the venous dilatation in the upper lobes (B) characteristic of severe mitral stenosis. The lower lobe veins are narrowed and hard to see. 


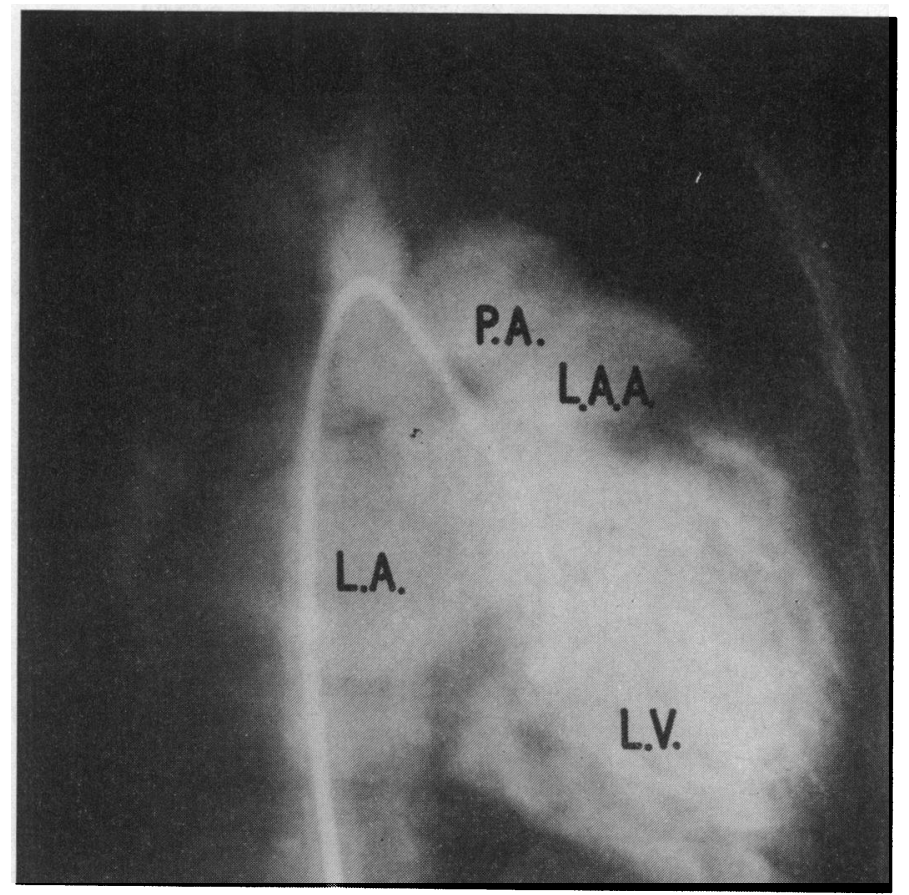

FIG. 8.-Left ventricular angiocardiogram in patient 7 showing severe mitral incompetence. Note the large left atrial appendage (L.A.A.), the opacified pulmonary artery (P.A.) and the right aortic arch. (L.V.=left ventricle.)

directly demonstrated, but the presence of mitral obstruction was inferred from prolonged opacification of the left atrium in 3 patients (Nos. 1, 2, and 8), where contrast material remained in the chamber for 5,3 , and 5 seconds respectively. In ventricular septal defect patients with pulmonary vascular disease of similar severity to these patients but without mitral stenosis, the left atrium was never opacified for more than one second, demonstrating that restriction of inflow to the atrium was not a cause of the prolonged opacification.

Ventricular Defect. The presence of a ventricular septal defect was shown angiocardiographically by right ventricular injection in 2 patients (No. 1 and 2) and by left ventricular injection in 3 $(6,7$, and 8$)$ : in the latter a supracristal defect was shown.

\section{HÆMODYNAMIC INVESTIGATIONS}

Right heart catheterization was performed in all patients and the results are shown in Table III. Pulmonary hypertension of moderate to severe degree was present in all and was associated with an increase in calculated pulmonary vascular resistance in all but one. As mentioned elsewhere, however (Hollman et al., 1963), this calculated resistance can seriously underestimate the severity of the accompanying pulmonary vascular disease in VSD, as it does for example in patient No. 1. The left atrial pressure was measured directly in 2 (via an atrial septal defect in No. 4 and by transseptal puncture in No. 8), and indirectly by the pulmonary artery wedge pressure in 3 . The mean pressure was high in 4 and slightly raised in one. In 2 the mean pressure was within the range found in uncomplicated ventricular septal defect, but in one of them, with severe mitral incompetence, there was a very tall " $v$ " wave. The size of the left-to-right shunt was lower than that usually found with large ventricular septal defects, and this reflected the constant presence of considerable pulmonary hypertension.

Indicator dye dilution curves were useful in showing unequivocally in 3 patients that the arterial 
TABLE III

Hamodynamic Observations Before and After Operation

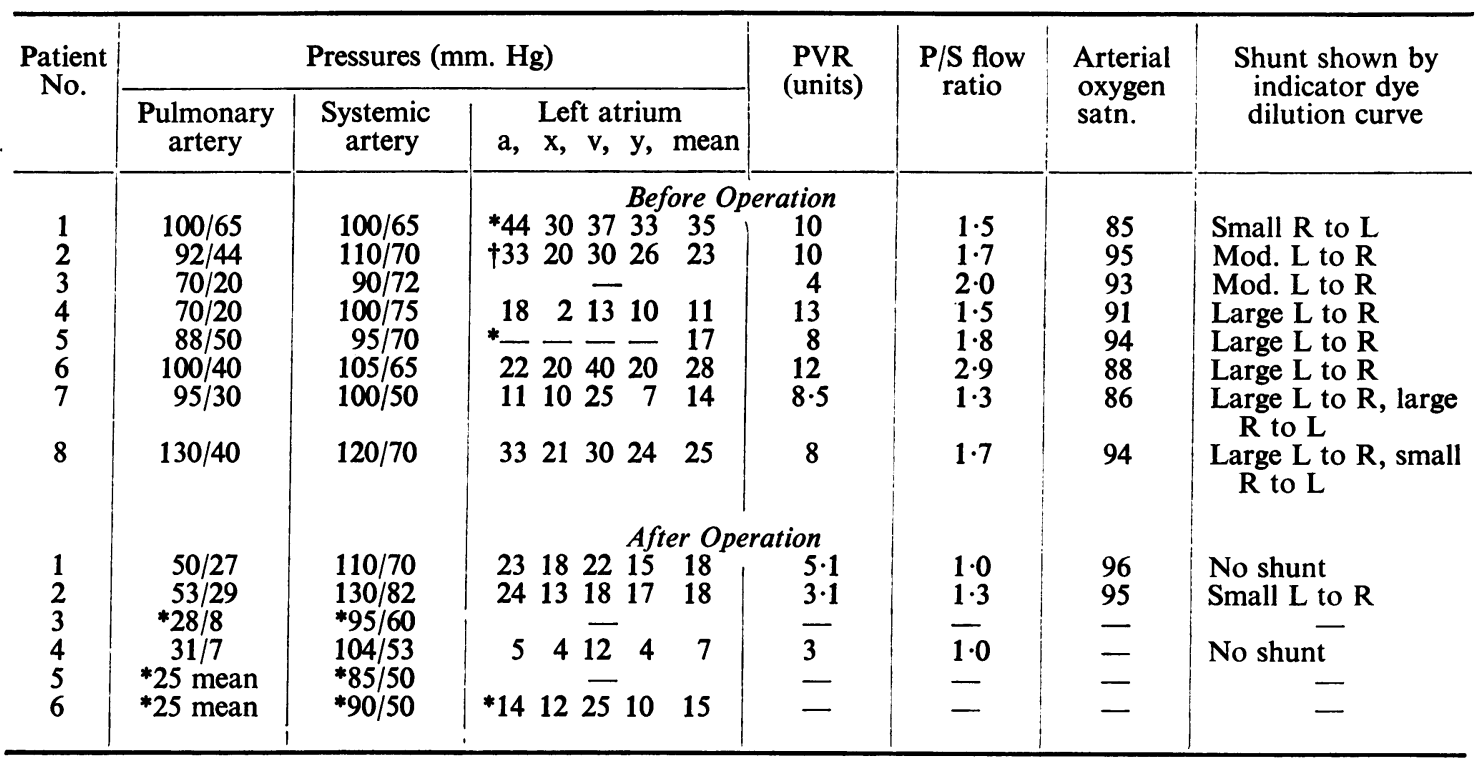

* Pressures measured at operation.

$\uparrow$ Wedge pressure.

$\mathbf{P V R}=$ pulmonary vascular resistance $; \mathrm{P} / \mathrm{S}=$ pulmonary $/$ systemic.

desaturation was due to a right-to-left shunt. Regional pulmonary blood flow was assessed in 2 patients by Dr. C. T. Dollery, using a radioactive gas technique (Dollery and West, 1960). In one with severe mitral stenosis (No. 1) the clearance ratio of 4.04 between the upper and lower zones indicated that there was a relative diminution in the blood flow to the lower part of the lung. In another (No. 2), with moderate stenosis, the clearance ratio of 1.02 was the same as that which is found in uncomplicated ventricular septal defect.

\section{SuRgical Treatment}

Using extracorporeal circulation the ventricular septal defect was closed at operation in the first 6 patients.

In one (patient No. 4), a $3 \times 2 \mathrm{~cm}$. defect was present in the muscular portion of the septum and was closed by direct suture: the septal cusp of the mitral valve was seen through the defect and noted to have a nodular edge. A $1 \times 1 \mathrm{~cm}$. secundum type atrial septal defect was repaired also. In another (patient No. 5) a huge supracristal defect measuring $5 \times 5 \mathrm{~cm}$. was closed with a Teflon patch. In the other 4 patients the defect was infracristal: it measured $3 \times 3 \mathrm{~cm}$. in 2 (No. 1 and 6), and a Teflon patch was used for closure. In 2 (Nos. 2 and 3), the defect was $2 \times 2 \mathrm{~cm}$. and $2 \times 1 \mathrm{~cm}$. respectively, and was closed by direct suture.

The mitral lesion was operated on only in one (No. 1). Mr. W. P. Cleland exposed the heart via a median sternotomy and the left atrium was entered through an incision placed just behind the interatrial groove. About $2 \mathrm{~cm}$. above the mitral valve there was a marked ring-like narrowing of the atrium leaving an orifice of little more than $1 \mathrm{~cm}$. The cusps of the mitral valve were seen beyond this constriction; they ballooned back during ventricular systole and appeared to be normal. The annular constriction was incised in two places and dilated, but it was possible to achieve only a $2 \mathrm{~cm}$. opening by these means. The ventricular septal defect was then repaired via a right ventriculotomy. The pressure gradient across the mitral valve was considerably reduced by this operation as shown in Table III and Fig. 9. 
An operation was not advised in patient

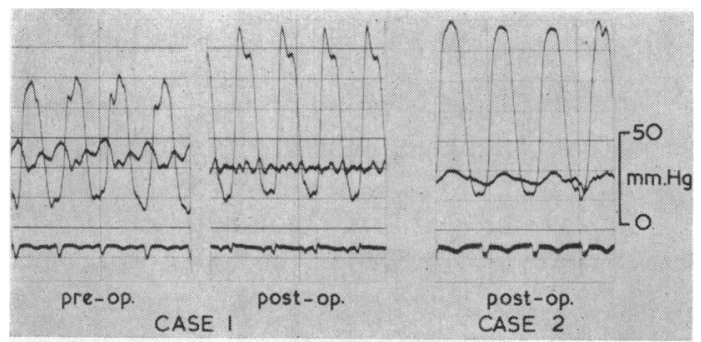

Fig. 9.-Pressure recordings from left atrium and left ventricle taken during operation. In patient 1 a supravalvar ring was dilated in addition to the ventricular septal defect being closed, but in patient 2 , only the ventricular septal defect was operated on.
No. 7 who had severe mitral incompetence and a large right-to-left shunt, and patient No. 8 declined operation.

\section{Post-OPERATIVE Results}

Patient No. 6 died 2 days after operation with pulmonary complications and complete heart block. At necropsy, the pleural cavities contained a considerable amount of blood-stained fluid and both lungs were collapsed. The left atrium was a large chamber with considerable endocardial thickening. Immediately above the mitral ring were two ridges of somewhat fibrotic endocardial thickening, one on the posterior wall immediately above the posterior

cusp and a smaller one above the postero-medial commissure. The mitral valve showed slight thickening of the anterior cusp with rather short and thick chordæ and measured $8.5 \mathrm{~cm}$. in circumference. The ventricular septal defect was well closed.

Patient No. 4 developed severe pulmonary complications three days after operation, but after being very ill for a while made a good recovery as did the other 4 patients.

The 5 survivors have now been followed for periods ranging from four to six years. In patient No. 1 it was clear soon after operation that mitral incompetence was present and though his pulmonary artery pressure had been reduced by one-half he developed congestive failure which is still present four years later: his exercise tolerance has, however, improved. The other patients are all well and are greatly improved symptomatically.

On auscultation there is a systolic murmur due to a small residual ventricular septal defect in patient No. 2 only. Patient No. 1 has loud mitral systolic and diastolic murmurs, patient No. 2 a loud diastolic murmur, patient No. 3 a moderate diastolic murmur, patient No. 4 moderate systolic and diastolic murmurs, and patient No. 5 has no murmurs.

Moderate pulmonary hypertension persists in 2 patients (Nos. 1 and 2) (see Table III) associated with mitral incompetence in the former and with mitral stenosis and a small residual shunt in the latter. A slight rise of pulmonary artery pressure is present in the other 3 patients. Acetylcholine was injected into the pulmonary artery during post-operative right heart catheterization in 3 patients (Nos. 1, 2, and 4), and in one (No. 1) a selective fall in pulmonary artery pressure was observed.

\section{DISCUSSION}

The chief clinical problem in the diagnosis of these patients was to distinguish the murmur of mitral stenosis from the apical diastolic flow murmur of a lone ventricular septal defect, and to separate the murmur of mitral incompetence from the systolic murmur produced by the ventricular defect. The presence of a presystolic thrill or murmur pointed clearly to the presence of mitral stenosis in 3 of the 5 patients with this lesion, as emphasized by Daoud et al. (1963), and a loud opening snap led to diagnosis in a fourth. In one (No. 3) associated mitral disease was not suspected until a long diastolic bruit persisted after operation. In those with mitral incompetence it was diagnostically fortunate that the accompanying pulmonary hypertension shortened the length of the ventricular septal defect murmur and this made it comparatively easy to appreciate that the apical pansystolic murmur was produced at the mitral valve. The radiation and different quality of the mitral incompetent bruit were also useful distinguishing features. The electrocardiogram and chest radiograph gave extra diagnostic help in a few patients but the most useful confirmatory evidence 


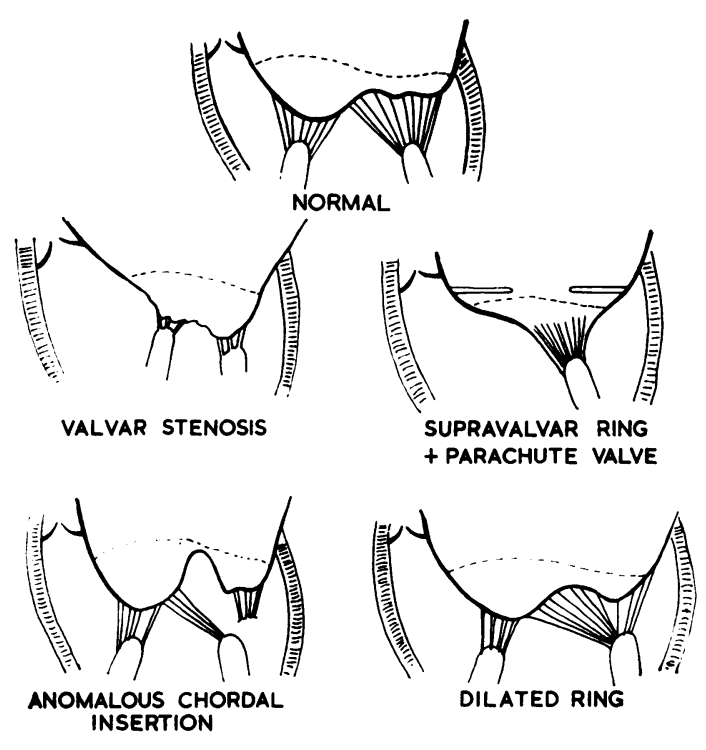

FIG. 10.-Diagrammatic representation of the varieties of mitral valve disease known to occur in association with ventricular septal defect. came from the angiocardiogram. A rightsided injection in those with mitral stenosis demonstrated the delay in emptying of the left atrium, which others (Hilbish and Cooley, 1956) have also found of great value: and the left ventricular angiocardiogram (Steiner and Hollman, 1962) showed clearly the presence or absence of mitral incompetence. The virtually normal size of the left atrium in the patient with the most severe mitral obstruction should be emphasized for it is an unexpected finding that could deflect attention from the mitral valve. Baker et al. (1962) also had a patient with congenital mitral stenosis in whom the left atrium was normal in size.

In the belief that congenital mitral disease could be resistant to surgical correction we were perhaps too conservative in making an attack on the mitral lesion in only one patient (with severe mitral stenosis), for since then there have been favourable reports of operations in both mitral stenosis (Braudo et al., 1957; Starkey, 1959) and mitral incompetence (Talner, Stern, and Sloan, 1961 ; Levy et al., 1963) without the use of prostheses.

Because artificial valves may have a limited application in the young on account of the small size of the valve ring in the stenotic cases and the problem of growth in all, we have thought it worth while as a surgical guide to compile a list (Table IV) of all the recorded causes of congenital mitral disease. Fig. 10 shows diagrammatically the types of mitral disease known to occur in association with ventricular septal defect. The supravalvar stenosing ring is possibly the most common and might appear to be the most favourable for surgical attack. In our own case this proved not to be so, for although the stenosis was partially relieved the apparently normal underlying valve was incompetent after operation. We speculate that this may be due to improper chordal attachments which now allow the valve cusps to prolapse back into the atrium past the former tight stenosis. Chordal involvement from endocardial fibro-elastosis has in fact been observed by Johnson and Dodd (1957) and by Rogers et al. (1955) in 2 patients with supravalvar stenosing rings. Apart from two uncertainly documented cases of Manubens, Krovetz, and Adams (1960) the only other case reported where both the supravalvar ring and the ventricular septal defect have been surgically repaired with long-term survival is that of Lynch et al. (1962). They were able to diagnose the ring before operation by noting a pressure gradient above the mitral valve when the left atrial pressure was measured by transbronchial needle puncture. The diaphragm contained two openings and after operation there was no mitral incompetence. Shone et al. (1963) have pointed out the very interesting fact that a "parachute" deformity of the mitral valve, where all the chordæ are inserted into a single papillary muscle with the production of subvalvar obstruction, is commonly associated with a supravalvar ring, subaortic stenosis, and coarctation of the aorta.

Turning to congenital mitral disease in general one finds that a considerable variety of pathological processes may lead to stenosis or incompetence and these are summarized in Table IV. It is, of course, appreciated that both stenosis and incompetence exist together in a number of patients. Perhaps the most important factor of all in congenital mitral disease is deficiency, malposition, or fusion of chordæ tendineæ. Indeed, there are reported cases of both stenosis and incompetence 
TABLE IV

Main Types of Congenital Mitral Valve Disease occurring either with or without Septal Defects, but ExCluding Corrected Transposition and Endocardial CuShion Defect

\begin{tabular}{|c|c|c|c|c|c|c|c|c|}
\hline \multicolumn{8}{|c|}{ Valve lesion } & Authors \\
\hline \multicolumn{9}{|c|}{ Mitral Stenosis } \\
\hline Supravalvar stenosing $\mathbf{r}$ & ing & $\ldots$ & . & . & . & . & . & Rogers et al. (1955) \\
\hline Parachute valve ... & . & . & . & . & .. & . & . & Shone et al. (1963) \\
\hline Accessory valve tissue & .. & . & - & . & . & . & . & $\begin{array}{l}\text { Fontana and Edwards } \\
(1962)\end{array}$ \\
\hline Fibrous band below val & lve & . & $\cdots$ & . & . & $\cdots$ & . & Daoud et al. (1963) \\
\hline \multicolumn{8}{|c|}{ Mitral Incompetence } & \\
\hline Anomalous short or $\mathrm{ab}$ & sent & lordæ & . & . & $\cdots$ & $\cdots$ & . & Talner et al. (1961) \\
\hline Dilated annulus ... & . & .. & .. & . & . & . & . & Levy et al. (1963) \\
\hline Double mitral orifice & .. & . & . & . & $\cdots$ & . & . & $\begin{array}{l}\text { Edwards and } \\
\text { Burchell (1958) }\end{array}$ \\
\hline Anterior cusp deficient & $\ldots$ & $\ldots$ & . & $\cdots$ & $\cdots$ & $\ldots$ & $\ldots$ & Kjellberg et al. (1959) \\
\hline Cleft anterior cusp & .. & $\ldots$ & . & . & . & . & . & Edwards (1960) \\
\hline
\end{tabular}

where chordal abnormalities were the primary lesion with quite normal valve cusps. A curious extra cause of mitral stenosis is found sometimes in cases of gargoylism where the cusps are infiltrated with acid mucopolysaccharides (Vanace, Friedman, and Wagner, 1960).

In our own patients we have reasonable evidence in 6 (Nos. 1-4, and 6 and 7) that the mitral lesion was congenital because apart from the young age of the patients and the lack of rheumatic history, there were other congenital cardiac defects in 2 (atrial septal defect in one, right aortic arch in one), and the obviously congenital supravalvar ring in one. In this connexion it seems unlikely, at least in most cases, that such a ring results from accretion of fibrous tissue on jet lesions produced by an incompetent valve as was suggested by Rogers et al. (1955). In 2 patients (5 and 8) aged 19 and 22 respectively, it is certainly possible that the lesion was rheumatic in spite of the negative history, and the opening snap in patient No. 5 might favour a rheumatic ætiology. However, the low incidence of mitral disease in ventricular septal defect $(3.6 \%$ in this series) as compared to atrial septal defect $(9.6 \%$ Bedford, 1961), where the lesion is usually rheumatic, probably reflects the different causative factors in the two lesions.

It was stated by Ferencz et al. in their classic paper of 1954 that congenital mitral disease was usually combined with other cardiac abnormalities, but since that time roughly equal numbers of isolated and combined lesions have been reported. An important and still neglected factor in discussions on the incidence of various lesions is that of age, for the infant age-group (under 1 year) contains a very different spectrum of malformations compared to that of older children. This concept is well illustrated by the finding of Hastreiter et al. (1963) that of 22 infants with aortic stenosis no less than 50 per cent had associated mitral stenosis or incompetence, whereas in 36 children with aortic stenosis aged 2 to 10 years studied by Braunwald et al. (1963) not one had mitral disease. Patients with isolated mitral lesions probably survive longer than these with associated defects, and are hence more likely to come to operation and then be reported. When mitral valve disease does occur with other cardiac lesions the associated abnormality is nearly always left sided, and thus, in addition to aortic stenosis, it is common to find coarctation of the aorta or patent ductus arteriosus. Associated ventricular septal defect is uncommon and atrial septal defect rare.

\section{SUMMARY}

Associated mitral valve disease was found in 8 of 221 patients with ventricular septal defect, an incidence of 3.6 per cent. The mitral lesion was dominantly stenotic in 5 .

The auscultatory features of the mitral lesion had to be separated from the bruits occurring with 
lone ventricular septal defect. Those of especial value were a presystolic murmur, a loud first sound, and an opening snap in the stenotic cases, and a pansystolic apical murmur in those with incompetence, which contrasted either in duration or quality with the murmur of the ventricular septal defect. All patients had a long and loud mitral diastolic murmur which helped to draw attention to the mitral valve.

Angiocardiography was of considerable diagnostic value. In the patient with stenosis there was prolonged opacification of the left atrium following a right-sided injection. In the patients with incompetence injection into the left ventricle demonstrated the regurgitation.

Operative closure of the ventricular septal defect was undertaken in 6 patients in one of whom a mitral supravalvar stenosing ring was also treated by operation.

A review is presented of all the known anatomical varieties of mitral valve disease that occur either with ventricular septal defect or alone, and the surgical implications are discussed.

The advice and encouragement of Professor J. F. Goodwin is warmly acknowledged as is the help given by our surgical colleagues, Mr. W. P. Cleland, Mr. H. H. Bentall, and Dr. D. Melrose. Dr. R. E. Bonham Carter referred patient No. 3 and we thank him for his support of our work. We are grateful to Mr. A. C. Lees, Mr. P. Luther, and Mr. G. Williams for the illustrations. Mrs. Angela Cartwright gave valued secretarial help.

\section{REFERENCES}

Baker, C. G., Benson, P. F., Joseph, M. C., and Ross, D. N. (1962). Congenital mitral stenosis. Brit. Heart J., 24, 498.

Bedford, D. E. (1961). Atrial septal defect. Proc. roy. Soc. Med., 54, 779.

Bower, B. D., Gerrard, J. W., D'Abreu, A. L., and Parsons, C. G. (1953). Two cases of congenital mitral stenosis treated by valvotomy. Arch. Dis. Childh., 28, 91.

Braudo, J. L., Jarett, S. N., Adler, D. I., and Kessel, I. (1957). Isolated congenital mitral stenosis. Circulation, 15, 358.

Braunwald, E., Goldblatt, A., Aygen, M. M., Rockoff, S. D., and Morrow, A. G. (1963). Congenital aortic stenosis. 1. Clinical and hemodynamic findings in 100 patients. Circulation, 27, 426.

Campbell, M., and Missen, G. A. K. (1957). Endocardial cushion defects: Common atrio-ventricular canal and ostium primum. Brit. Heart J., 19, 403.

Cleland, W. P., Beard, A. J. W., Bentall, H. H., Bishop, M. B., Braimbridge, M. V., Bromley, L. L., Goodwin, J. F., Hollman, A., Kerr, W. F., Lloyd-Jones, E. B., Melrose, D. G., and Telivuo, L. J. (1958). The treatment of ventricular septal defect. Brit. med. J., 2, 1369.

Daoud, G., Kaplan, S., Perrin, E. V., Dorst, J.P., and Edwards, F. K. (1963). Congenital mitral stenosis. Circulation, $27,185$.

Dollery, C. T., and West, J. B. (1960). Regional uptake of radioactive oxygen, carbon monoxide and carbon dioxide in the lungs of patients with mitral stenosis. Circulat. Res., 8, 765 .

Edwards, J. E. (1960). In Pathology of the Heart, 2nd ed., ed. S. E. Gould. Thomas, Springfield, Illinois.

, and Burchell, H. B. (1958). Pathologic anatomy of mitral insufficiency. Proc. Mayo Clin., 33, 497.

Elliott, L. P., Anderson, R. C., Amplatz, K., Lillehei, C. W., and Edwards, J. E. (1962). Congenital mitral stenosis. Pediatrics, 30, 552.

Ferencz, C., Johnson, A. L., and Wiglesworth, F. W. (1954). Congenital mitral stenosis. Circulation, 9, 161.

Fontana, R. S., and Edwards, J. E. (1962). Congenital Cardiac Disease. A Review of 357 Cases Studied Pathologically. Saunders, Philadelphia, and London.

Goodwin, J. F., Steiner, R. E., and Lowe, K. G. (1952). The pulmonary arteries in mitral stenosis demonstrated by angiocardiography. J. Fac. Radiol. (Lond.), 4, 21.

Hastreiter, A. R., Oshima, M., Miller, R. A., Lev, M., and Paul, M. H. (1963). Congenital aortic stenosis syndrome in infancy. Circulation, 28, 1084.

Helmholz, H. F., Daugherty, G. W., and Edwards, J. E. (1956). Congenital "mitral" insufficiency in association with corrected transposition of the great vessels. Proc. Mayo Clin., 31, 82.

Hilbish, T. F., and Cooley, R. N. (1956). Congenital mitral stenosis: Roentgen study of its manifestations. Amer. J. Roentgenol., 76, 743.

Hollman, A., Goodwin, J. F., and Basta, L. (1962). Cardiographic assessment of pulmonary vascular disease in ventricular septal defect. Brit. Heart J., 24, 529.

-, Morgan, J. J., Goodwin, J. F., and Fields, H. (1963). Auscultatory and phonocardiographic findings in ventricular septal defect. Circulation, 28, 94.

Johnson, N. J., and Dodd, K. (1957). Obstruction to left atrial outflow by a supravalvular stenosing ring. J. Pediat., $51,190$.

Kjellberg, S. R., Mannheimer, E., Rudhe, V., and Jonsson, B. (1959). Diagnosis of Congenital Heart Disease, 2nd ed. Year Book Publishers, Chicago.

Levy, M. J., Varco, R. L., Lillehei, C. W., and Edwards, J. E. (1963). Mitral insufficiency in infants, children, and adolescents. J. thorac. Surg., 45, 434.

Lynch, M. F., Ryan, N. J., Williams, G. R., Cayler, G. G., Richardson, W. R., Campbell, G. S., and Taybi, H. (1962). Preoperative diagnosis and surgical correction of supravalvular mitral stenosis and ventricular septal defect. Circulation, 25, 854. 
Manubens, R., Krovetz, L. J., and Adams, P. (1960). Supravalvular stenosing ring of the left atrium. Amer. Heart $J ., 60,286$.

Morgan, J., Pitman, R., Goodwin, J. F., Steiner, R. E., and Hollman, A. (1962). Anomalies of the aorta and pulmonary arteries complicating ventricular septal defect. Brit. Heart J., 24, 279.

Rogers, H. M., Waldron, B. R., Murphey, D. F. H., and Edwards, J. E. (1955). Supravalvular stenosing ring of left atrium in association with endocardial sclerosis (endocardial fibroelastosis) and mitral insufficiency. Amer. Heart J., 50, 777.

Shone, J. D., Sellers, R. D., Anderson, R. C., Adams, P., Lillehei, C. W., and Edwards, J. E. (1963). The developmental complex of "parachute mitral valve", supravalvular ring of left atrium, subaortic stenosis, and coarctation of aorta. Amer. J. Cardiol., 11, 714.

Starkey, G. W. B. (1959). Surgical experiences in the treatment of congenital mitral stenosis and mitral incompetence. J. thorac. Surg., 38, 336.

Steiner, R. E., and Hollman, A. (1962). Radiological contrast studies of the left heart. Brit. J. Radiol., $35,540$.

Talner, N. S., Stern, A. M., and Sloan, H. E. (1961). Congenital mitral insufficiency. Circulation, 23, 339.

Vanace, P. W., Friedman, S., and Wagner, B. M. (1960). Mitral stenosis in an atypical case of gargoylism. Circulation, 21, 80 . 